\title{
Communication difficulties and strategies used by the nurses and their team in caring for the hearing impaired
}

\author{
Dificuldades de comunicação e estratégias utilizadas pelos enfermeiros e sua equipe na \\ assistência ao deficiente auditivo
}

\author{
Fernanda da Rocha Britto ${ }^{1}$, Maria Mercedes Fernandez Samperiz ${ }^{2}$
}

\begin{abstract}
Objectives: To identify communication difficulties faced by the nursing staff and to learn the strategies developed for non-oral communication. Methods: This is a descriptive, exploratory, level I study with a quantitative approach. The sample group comprised 37 registered nurses and 63 licensed practical nurses of a private hospital who, after undergoing the ethical-legal procedures, answered a questionnaire to identify difficulties faced and strategies used in the care for hearing-impaired patients. Results: Difficulty in explaining matters of interest to the patient was reported by $66 \%$ of professionals; and $32 \%$ reported difficulties in understanding patients in their way of communicate. The strategy adopted by $100 \%$ of respondents was mimicry, followed by lip reading, used by $94 \%$ of respondents; help from a person accompanying the patient was used by $65 \%$, and written communication by $42 \%$ of respondents. Only $1 \%$ used communication via the Brazilian Sign Language (LIBRAS). Conclusions: The difficulties found and the strategies adopted by the nursing staff in communicating with hearing-impaired patients justify the need to train these professionals to deliver a more humanized care, developing a more inclusive society for those with special needs.
\end{abstract}

Keywords: Hearing impaired persons; Nonverbal communication; Nonverbal communication/nursing; Nonverbal communication/ education; Nursing, team/methods; Nursing, team/education; Humanization of assistance; Problem solving; Sign language; Deafness

\section{RESUMO}

Objetivo: Identificar as dificuldades de comunicação da equipe de enfermagem com os deficientes auditivos no decorrer da assistência de enfermagem e conhecer as estratégias desenvolvidas na comunicação não verbal. Métodos: Trata-se de um estudo de caráter descritivo, exploratório, de nível I, com abordagem quantitativa. A amostra foi constituída por 37 enfermeiros e 63 técnicos em enfermagem de um hospital privado que, depois de cumprirem os procedimentos ético-legais, responderam a um questionário para identificar dificuldades e estratégias utilizadas no atendimento ao deficiente auditivo. Resultados: Dificuldade em explicar assunto de interesse do paciente foi relatada por $66 \%$ dos profissionais e, para $32 \%$, dificuldade em entender o paciente a partir da sua forma de comunicação. A estratégia de comunicação utilizada por $100 \%$ dos pesquisados foi mímica, seguida por leitura labial, usada por $94 \%$, auxílio do acompanhante por $65 \%$ e escrita por $42 \%$. Somente $1 \%$ comunicou-se por meio de LIBRAS. Conclusões: As dificuldades encontradas e as estratégias utilizadas pela equipe de enfermagem na comunicação com pacientes deficientes auditivos justificam a necessidade de capacitar esses profissionais para promover uma assistência humanizada no contexto de uma sociedade mais inclusiva para portadores de necessidades especiais.

Descritores: Pessoas com insuficiência auditiva; Comunicação não verbal/enfermagem; Comunicação não verbal/educação; Equipe de enfermagem; Equipe de enfermagem/educação; Humanização da assistência; Resolução de problemas; Linguagem de sinais; Surdez

\section{INTRODUCTION}

Oral-auditory language or the spatial-visual channel enables the communication among individuals and enhances one's capacity to organize ideas and thoughts. Hearing loss compromises the main means of communication in our society and prevents access to oral-auditory communication ${ }^{(1)}$.

Communication may be defined as a process through which we share, send and receive messages, ideas, feelings and all sorts of emotions. It happens through the written and spoken word, and also through nonverbal mechanisms which may or may not influence the

\footnotetext{
Final paper presented at Faculdade de Enfermagem do Hospital Israelita Albert Einstein - HIAE, São Paulo (SP), Brazil.

${ }^{1}$ Nurse of Hospital Israelita Albert Einstein - HIAE, São Paulo (SP), Brazil.

${ }^{2} \mathrm{PhD}$ in Sciences; Lecturer at Faculdade de Enfermagem do Hospital Israelita Albert Einstein - HIAE, São Paulo (SP), Brazil.

Corresponding author: Fernanda da Rocha Britto - Rua José Bueno Bicalho, 425, BI. 6, apto. 73 - Vila das Mercês - CEP $04176-260$ - São Paulo (SP), Brazil - Tel.: 11 2083-7344 - e-mail: fernandaaiuka@gmail.com

Received on May 14, 2009 - Accepted on Dec 18, 2009
} 
behavior of people who will react to it based on their beliefs, values, background and culture ${ }^{(2)}$.

Hearing is the sense through which we perceive the sounds. In the case of the hearing impaired, the failure or lack of this sense interferes in one's relation with society ${ }^{(3)}$. Amongst all communication disorders, deafness is the most prevalent in Brazil, reaching rates of $60 \%$ among related disorders ${ }^{(4)}$.

Communication barriers faced by those with special needs are not perceived by other people, frequently because these barriers are of environmental nature ${ }^{(5)}$. As far as nurses are concerned, communication with patients is considered a process fundamental not only to identify signs, symptoms and problems that affect the patient, but also to consider the development of a therapeutic communication between healthcare professionals and patients ${ }^{(6)}$.

Therapeutic communication is the professional skill in using knowledge about communication to help people with temporary tension to overcome their problems, live better together with others, visualize the experience lived, adapt to what can not be changed, face the selfrealization blocks and help them find new behavioral patterns $^{(7)}$.

There are non-verbal communication techniques - for example, lip reading, Brazilian Sign Language (LIBRAS), mimicry, drawing, figures, writing, a companion present most of the time the patient is at the hospital, and body language; all these activities help in the therapeutic communication between the healthcare team and the patient ${ }^{(3)}$.

Some studies carried out with nursing professionals show that there are failures in non-verbal communication in the interaction with hearing loss patients, which characterizes the need for attention and training in order to not impair care delivered ${ }^{(3,4,7)}$.

The culture and language of hearing impaired patients are different, and must be understood and respected according to ethical principles. To communicate with these clients is a challenge, especially for healthcare professionals $^{(8)}$.

Through the communication established with the patients, the professionals are able to understand them as a holistic being and perceive their ideas of the world, that is, the way they think, feel and act, thus understanding their needs and being able to provide proper care, minimizing their discomfort ${ }^{(9)}$.

\section{OBJECTIVES}

To identify the communication difficulties of the nursing team with the hearing impaired patients throughout nursing care and to understand the strategies developed by the nursing team for non-verbal communication.

\section{METHODS}

This is a descriptive, exploratory, level I study, with a quantitative approach, carried out at Hospital Israelita Albert Einstein (HIAE), a private and large general hospital located in the southern region of the City of São Paulo ${ }^{(10)}$.

The sample was made up of registered nurses $(\mathrm{RN})$ and licensed practical nurses (LPN) in the Internal Medicine and Surgery units of the HIAE, throughout the three work shifts. The sample inclusion criteria were to have the professionals working with healthcare during the second semester of 2008, and acceptance to participate in this study after having signed the informed consent form.

Data was collected respecting ethical and legal principles, according to the standards present on Resolution 196/1996, after the research project was approved by the Scientific Committee of Faculdade de Enfermagem do Hospital Israelita Albert Einstein (Nursing School) and by the Research Ethics Committee of Hospital Israelita Albert Einstein.

For data collection, a questionnaire (Appendix) was prepared and consisted of two parts. The first was associated with the characteristics of the professionals, such as gender, age, professional classification, year of graduation, and work shift. The second part, made up of multiple choice questions, approached the difficulties that the nursing team faces in the care for hearingimpaired patients, as well as the strategies used for nonverbal communication.

\section{RESULTS}

One hundred nursing professionals, 37 nurses (37\%) and $63 \mathrm{LPN}(63 \%)$ were interviewed. Most nurses were females $(61 \%)$, as shown in figure 1.

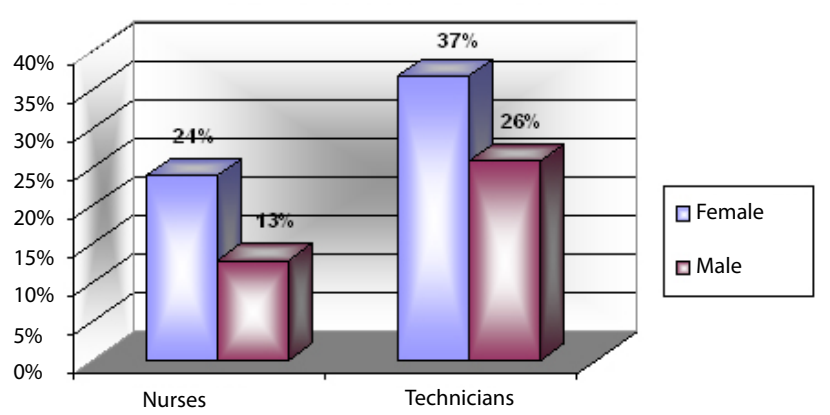

Figure 1. Characterization of the interviewees per gender and professional category

The age of these professionals varied between 23 and 52 years, and the age range of $48 \%$ of the interviewees was between 30 and 36 years, while $56 \%$ of professionals had between 11 and 20 years of experience in the field, as shown in figures 2 and 3. 


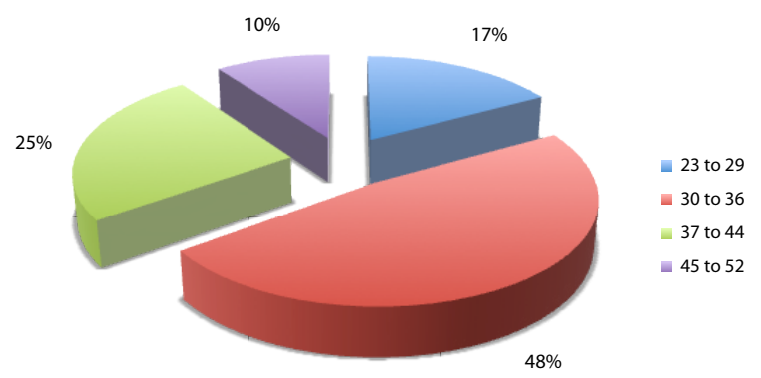

Figure 2. Characterization of the interviewees per age group

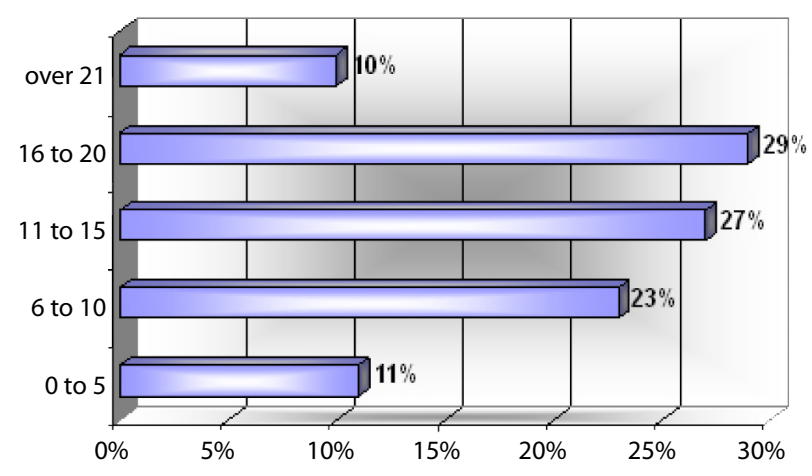

Figure 3. Years of professional experience

This study was conducted with professionals working in three shifts, $28 \%$ in the morning, $57 \%$ in the afternoon and $15 \%$ in the night shift. Among the interviewees, $97 \%$ had cared for patients with hearing impairment and 3\% - three LPN - stated that they had not had any contact with hearing-impaired individuals at the hospital. Therefore, out of the 97 interviewees who cared for patients with hearing impairment, 37 were RN and 60 were LPN and answered the issues regarding communication difficulties and strategies used for communication between the nursing team and hearing impaired patients.

Figure 4 depicts communication difficulties with hearing impaired patients, highlighted by the nursing team. Difficulties in explaining topics of the patient's interest were reported by $57 \%$ of RN (21) and $72 \%$ of LPN (43), which represents answers from $66 \%$ of all the interviewees (64). For 31 interviewees (32\%), the difficulty was in understanding the patient based on his/her means of communication, and this answer was chosen by $43 \%$ of RN (16) and by $25 \%$ of LPN (15). Two licensed practical nurses did not report difficulties in communicating with patients, since they were partially hearing-impaired themselves and used hearing aids (Figure 4).

The nursing team reported more than one communication strategy used in the care for these

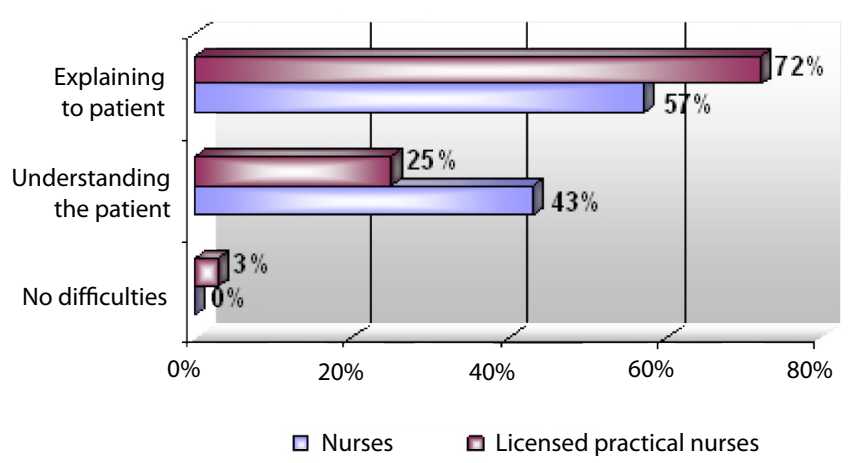

Figure 4. Communication difficulties faced by RN and LPN in care of hearing impaired patients

patients. Thus, when asked about the strategies used, considering both RN and LPN, all the interviewees $(100 \%)$ reported using mimicry to communicate with hearing impaired patients. Lip reading was reported by $94 \%$ of professionals as the means of communication mostly used by the patients. The help of a companion $(65 \%)$ and writing (42\%) were also used as communication strategies. Only $1 \%$ used the Brazilian Sign Language (LIBRAS) to communicate and $2 \%$ used other means of communication (Figure 5).

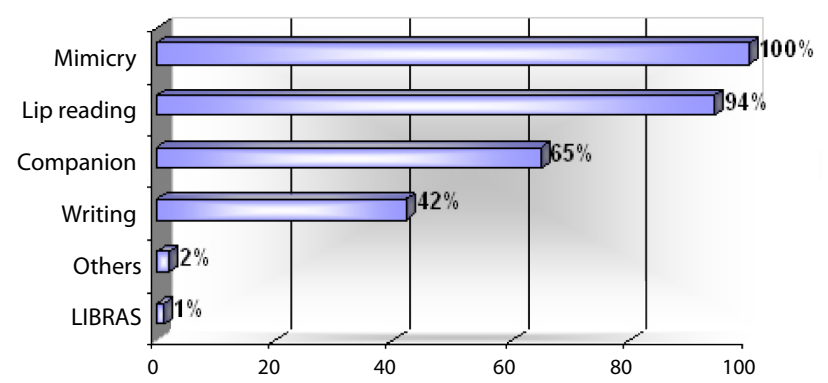

Figure 5. Percentage of professionals who mentioned communication strategies

Among the strategies used by the healthcare professionals that assisted hearing impaired individuals, mimicry was mentioned by $100 \%$ of professionals, 37 $\mathrm{RN}$ and $60 \mathrm{LPN}$; lip reading was reported by $34 \mathrm{RN}$ (92\%) and by 57 LPN (95\%); one LPN (2\%) reported using LIBRAS; writing was used by seven RN (19\%) and by 34 LPN (56\%); communication through the escort was reported by $16 \mathrm{RN}(43 \%)$ and $47 \mathrm{LPN}(78 \%)$ and two licensed practical nurses $(2 \%)$ used other means of communication (Table 1).

When asked about when the nursing team should be trained to provide care to people with special needs, $100 \%$ of the RN (37) said it should happen during 
Table 1. Communication strategies used by the nursing team in care of hearing-impaired patients

\begin{tabular}{|c|c|c|c|c|c|c|c|c|c|c|c|c|}
\hline \multirow{3}{*}{ Profissionals } & \multicolumn{12}{|c|}{ Communication strategies } \\
\hline & \multicolumn{2}{|c|}{ Mimicry } & \multicolumn{2}{|c|}{ Lip reading } & \multicolumn{2}{|c|}{ LIBRAS } & \multicolumn{2}{|c|}{ Writing } & \multicolumn{2}{|c|}{ Companion } & \multicolumn{2}{|c|}{ Others } \\
\hline & $\mathbf{n}$ & $\%$ & $\mathbf{n}$ & $\%$ & $\mathbf{n}$ & $\%$ & $\mathbf{n}$ & $\%$ & $\mathbf{n}$ & $\%$ & $\mathbf{n}$ & $\%$ \\
\hline Nurses & 37 & 100 & 34 & 92 & 0 & 0 & 7 & 19 & 16 & 43 & 0 & 0 \\
\hline Licensed practical nurses & 60 & 100 & 57 & 95 & 1 & 2 & 34 & 56 & 47 & 78 & 2 & 3 \\
\hline
\end{tabular}

their studies. For $77 \%$ of LPN (46), this training should be taken during work, while $23 \%$ (14) reported that training should be given during their studies and during work as well. None of the interviewees said training should occur based on their own initiative, through independent programs, specialization courses or others means.

\section{DISCUSSION}

Within the hospital setting - which creates lack of confidence due to its characteristics - patients must feel safe and trust the professionals in order to deliver care, and this trustworthiness bond depends on interpersonal communication $^{(2,7)}$.

In the present study, to explain an issue of interest to the hearing-impaired patient was a communication difficulty reported by most registered nurses and licensed practical nurses. However, the minority of RN and LPN found difficult communicating with the patient based on his/her means of communication.

The difficulties reported involve people with difficulties to perceive and emit non-verbal messages, or processing them. The results of the present study are confirmed by literature data, in which $\mathrm{RN}$ and LPN cannot use oral/auditory language and, which may cause problems in interacting with hearing-impaired patients $^{(11)}$.

Some studies show that healthcare professionals need to better communicate with the hearing impaired to avoid their frustration with health care, such as a feeling of hopelessness and impatience from the nursing professionals ${ }^{(12)}$. Notwithstanding, despite the studies, reports and case reports, healthcare services have neglected this both in public and private sectors ${ }^{(13)}$.

It is important to understand the patient within his/her individual needs, assessing organic and psychological aspects in order to properly systematize nursing care ${ }^{(14)}$.

Regarding the strategies used by health care professionals to communicate with hearing-impaired patients, the results obtained show that the entire nursing team - RNs and LPN alike - used mimicry during their work. Lip reading was used by almost all professionals, the help from an escort by the majority and the writing by the minority. Rarely communication was done using the Brazilian Sign Language (LIBRAS).
The other means of communication mentioned by some LPN corresponded to the patients who use hearing aids and did not have communication difficulties.

Mimicry is a compensatory communication strategy, because movement, gestures and facial expression are perceived by vision. Notwithstanding, studies have shown that the symbolic function of mimicry is not always understood, since it started in primitive ages and has substantially changed along the centuries, leading individuals to interpret differently the gestures based on their own ways of thinking ${ }^{(15)}$.

Lip reading is viable in interacting with the hardof-hearing listener, but it is not responsible for understanding itself, since the hearing challenged have to keep focused on the person he/she is communicating with, for any change in face position may cause loss of information. Nonetheless, lip reading, a very much used strategy, is overestimated and can cause specific problems in the patient-nurse relationship ${ }^{(16)}$.

To count on the escort's help to communicate with the patient would be a possible resource for a better interpersonal relationship between the patient and the nursing team, since the companion understands each gesture, each symbol, each facial expression used by the patient for communicating. However, in order to have the escort continuously present, it is necessary to have the team ready for it, since a hospital stay with the patient may cause conflicts and the hospital must have an environment that provides comfort for both - patient and escort ${ }^{(11,17)}$.

In the case of the institution where this study was carried out, the rooms are private and all patients are allowed to have an escort present during the entire stay.

It is often necessary to resort to writing, and it is a means of interpersonal communication, especially dealing with hearing impaired. However, such resource may be difficult to use, for people with hearing impairment since childhood have writing as a second language, and thus it can be difficult to master, causing embarrassment and frustration to the patient ${ }^{(11,14,18)}$.

Sign language is used worldwide, having its differences and particularities in each continent ${ }^{(11)}$. In Brazil, it is known as LIBRAS (Brazilian Sign Language). It is a modality that uses the visual space and hand coordination, and in some cases even noises, in which the signs and codes transmitted are received by 
the eyes and transmitted by the hands ${ }^{(11,19)}$. What sets it apart from mimicry is that each LIBRAS gesture means much more than one word. Depending on the context, with one gesture one can form an entire sentence. Usually, LIBRAS learning starts in childhood, making this form of communication easier; when hearing loss is acquired later, the hearing impaired person may be limited to the use of gestures alone ${ }^{(15,17,20)}$.

The nursing team must develop care practices, skills, instruments, techniques and competence to better communicate with patients ${ }^{(6)}$.

There are many barriers in carrying for the hearing challenged, and even if the meeting is temporary, it becomes a challenge for health care professionals to communicate with these individuals ${ }^{(21)}$. During the nursing course and also during the professional career, hearing impairment is discussed as a disease, without trying to find specific ways to interact with these patients $^{(12,21,22)}$.

It is necessary that health care professionals acquire knowledge about communication techniques by introducing specific courses in their syllabus curricula focusing on the care of people with special needs and/ or specialization programs and continuing education programs at the hospital.

\section{CONCLUSIONS}

Our findings show that the nursing team faces difficulties with regard to providing information to hearing impaired patients and in understanding the patient based on his/ her way of communicating. Healthcare professionals try to overcome these barriers through different strategies; but most of the interviewees use mimicry as a means of communication.

Training the health team in order to develop knowledge to assist the hearing-impaired patient's needs is very important to promote a humanized care highlighted on the context of a more inclusive society.

\section{REFERENCES}

1. Chaveiro N, Barbosa MA. A surdez, o surdo e seu discurso. Rev Eletrônica Enferm. 2004;6(2):166-71.

2. Silva LMG, Brasil VV, Guimarães HCQCP, Savonitti BHRA, Silva MJP. Comunicação não verbal: reflexões acerca da linguagem corporal. Rev Latinoam Enferm Ribeirão Preto. 2000;8(4):52-8.
3. Pagliuca LMF, Fiúza NLG, Rebouças CBA. Aspectos da comunicação da enfermeira com o deficiente auditivo. Rev Esc Enferm USP. 2007;41(3):411-8.

4. Costa SS. Audição, comunicação e linguagem: um convite à reflexão. Rev HCPA \& Fac Med Univ Fed Rio Gd do Sul. 1999;19(2):147-66.

5. Galvão CM, Sawada NO, Castro AP, Corniani F. Liderança e comunicação: estratégias essenciais para 0 gerenciamento da assistência de enfermagem no contexto hospitalar. Rev Latinoam Enferm Ribeirão Preto. 2000;8(5):34-43

6. Torres EF, Mazzoni AA, Mello AG. Nem toda pessoa lê em Braille, nem toda pessoa surda se comunica em língua de sinais. Educ Pesq. 2007;33(2): 369-85

7. Melles AM, Zazo MMF. A utilização da lousa mágica na comunicação do traqueostomizado. Rev Latinoam Enferm Ribeirão Preto. 2001;9(1):73-9.

8. Araújo MMT, Silva MJP, Puggina ACG. A comunicação não-verbal enquanto fator iatrogênico. Rev Esc Enferm USP. 2007;41(3):419-25.

9. Silva MJP. Aspectos gerais da construção de um programa sobre comunicação não-verbal para enfermeiros. Rev Latinoam Enferm Ribeirão Preto. 1996;4(e):25-37.

10. Polit DF, Beck CT, Hungler BP. Fundamentos de pesquisa em enfermagem: métodos, avaliação e utilização. 3a ed. Porto Alegre: Artmed; 2004. Capítulo 8, Compreensão do delineamento da pesquisa quantitativa, p. 163-98.

11. Chaveiro N, Barbosa MA, Porto CC. Revisão de literatura sobre o atendimento ao paciente surdo pelos profissionais da saúde. Rev Esc Enferm USP. 2008;42(3):578-83.

12. Gomes V, Correa Soares M, Manfrin Muniz R, Silva Junior DS. Vivencia del enfermero al cuidar sordos y/o portadores de deficiencia auditiva. Enferm Glob. 2009;17:1-10.

13. Pagliuca LMF, Fiúza NLG, Rebouças CBA. Aspecto da comunicação da enfermeira com o deficiente auditivo. Rev Esc Enferm USP. 2007;41(3):411-8.

14. Machado ACA, Brêtas ACP. Comunicação não-verbal de idosos frente ao processo de dor. Rev Bras Enferm. 2006;59(2):129-33.

15. Jesus SC. A dimensão mimética da linguagem. Arqueiro. 2006;14:7-10.

16. Botelho P. Educação inclusiva para surdos: desmistificando pressupostos. In: I Seminário Internacional Sociedade inclusiva; 1999 Set; Belo Horizonte. Anais eletrônicos. Belo Horizonte: PUC Minas; 2007:1-5 [citado 2010 Feb 9]. Disponível em: http://www.sociedadeinclusiva.pucminas.br/anaispdf/educsurdos.pdf

17. Rosa CG, Barbosa MA, Bachion MM. Comunicação da equipe de enfermagem com deficiente auditivo com surdez severa: um estudo exploratório. Rev Eletrônica Enferm. [Internet]. 2000 [citado 2010 Feb 9]; 2(2): [cerca de 6p.] Disponível em: http://www.fen.ufg.br/revista/revista2 2/melita.html

18. Brasil, Ministério da Educação e Cultura. Aquisição/aprendizagem da língua portuguesa (L2): o contexto da pessoa surda. [Internet]. 2004-2009 [citado 2010 Feb 9]. Disponível em: http://www.fonojp.hpgvip.ig.com.br/ebooks/ mec05.pdf

19. Dizeu LCTB, Caporali SA. A língua de sinais constituindo o surdo como sujeito. Educ Soc. 2005;26(91):583-97.

20. Cardoso AHA, Rodrigues KG, Bachion MM. Percepção da pessoa com surdez severa e/ou profunda acerca do processo de comunicação durante seu atendimento de saúde. Rev Latinoam Enferm. 2006;14(4):553-60.

21. Fávero MH, Pimenta ML. Pensamento e linguagem: a língua de sinais na resolução de problemas. Psicol Refl Crít. 2006;19(2):225-36.

22. Chaveiro N, Barbosa MA. Assistência de enfermagem na área da saúde como fator de inclusão social. Rev Esc Enferm USP. 2005;39(4):417-22. 
Appendix. Instrument for data collection

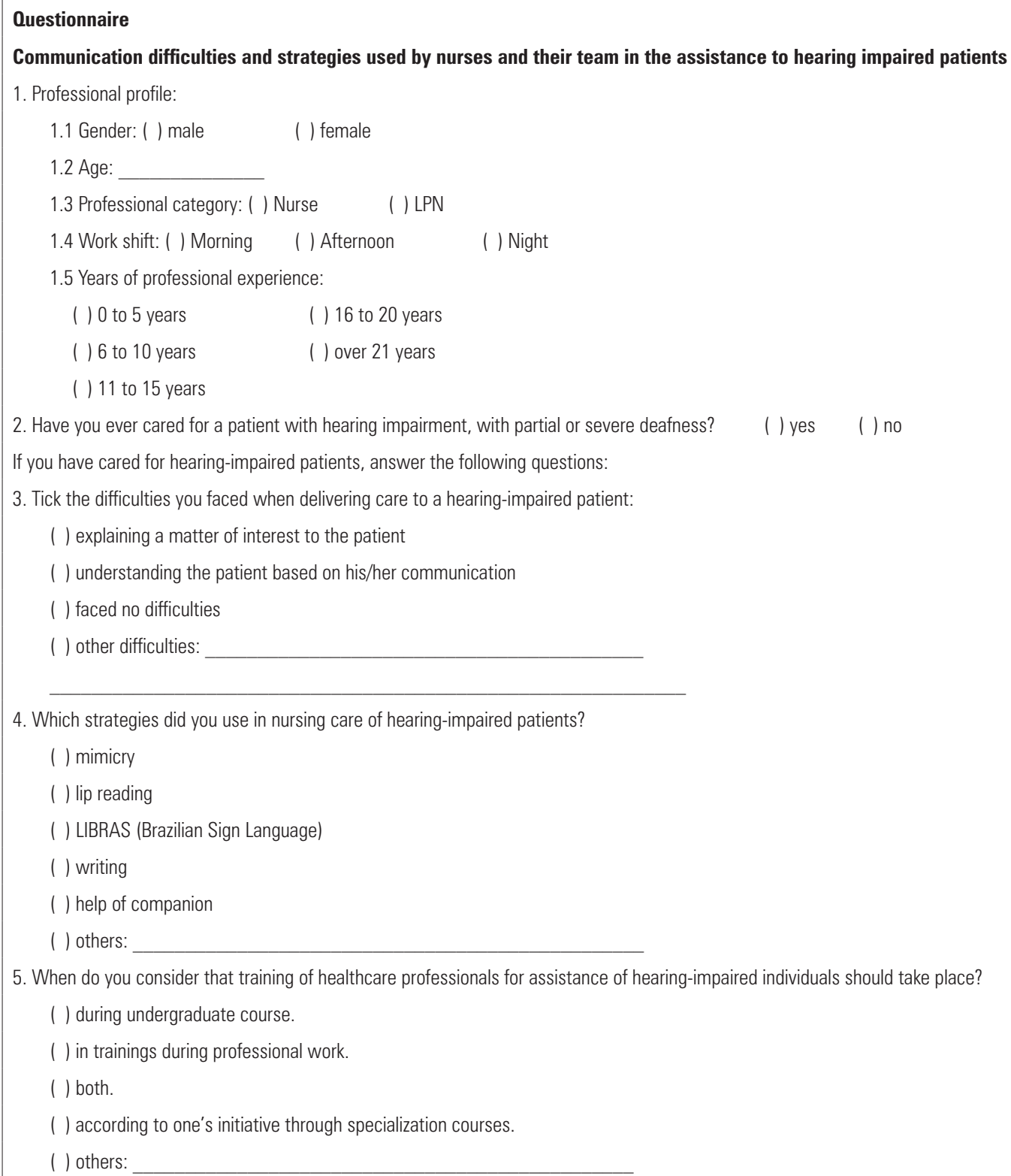

